\title{
Absorption of Amino Acids and Peptides in a Child with a Variant of Hartnup Disease and Coexistent Coeliac Disease
}

\author{
M. J. TARLOW, J. W. T. SEAKINS, JUNE K. LLOYD, D. M. MATTHEWS, B. CHENG, \\ and A. J. THOMAS \\ From the Departments of Child Health and Chemical Pathology, The Hospital for Sick Children, Great Ormond Street, \\ and Institute of Child Health, London; the Department of Experimental Chemical Pathology, Westminster Medical \\ School, London; and the Department of Biochemistry, Imperial College, London
}

Tarlow, M. J., Seakins, J. W. T., Lloyd, J. K., Matthews, D. M., Cheng, B., and Thomas, A. J. (1972). Archives of Disease in Childhood, 47, 798. Absorption of amino acids and peptides in a child with a variant of Hartnup disease and coexistent coeliac disease. A child with a variant of Hartnup disease and coexistent coeliac disease is described. Oral tolerance tests with L-histidine, L-tyrosine, and glycyl-L-tyrosine, and in vitro uptake studies on a small intestinal biopsy with L-histidine and glycyl-L-histidine, showed impaired absorption of the free amino acids, and showed that absorption of tyrosine and mucosal uptake of histidine was better from the dipeptides than from the free amino acids. This supports the hypothesis that the intestinal mucosa can take up small peptides intact, and that the peptide uptake mechanism is not involved in the intestinal defect of Hartnup disease.

It is now recognized that intestinal mucosal uptake of small peptides, with cellular hydrolysis, occurs in many mammals including man, and is probably an important mode of protein absorption (Newey and Smyth, 1959; Craft et al., 1968; Adibi, 1971; Matthews, 1971a). The nutritional importance of this mode of absorption in amino acid transport defects involving the small intestine was first suggested by investigations in a case of Hartnup disease (Navab and Asatoor, 1970; Asatoor et al., 1970). Tolerance tests showed that this patient absorbed L-histidine, L-tryptophan, and L-phenylalanine very poorly from the free amino acids, but comparatively well from dipeptides. It was suggested that retention of the ability to take up peptides, owing to the existence of an independent peptide transport system or systems, might explain the previously puzzling observation that there are no obvious symptoms of protein malabsorption in Hartnup disease, and no signs of malnutrition apart from a slight reduction in mean stature. Analogous findings were subsequently reported in cystinuria (Hellier, Perrett, and Holdsworth, 1970; Asatoor et al., 1971). We report

Received 28 February 1972. here a child with coeliac disease and a coexistent defect in intestinal and renal transport of neutral amino acids similar to, but not identical with, that present in classical Hartnup disease. Investigations of absorption of free amino acids and dipeptides by means of tolerance tests and transport studies in a jejunal biopsy have provided additional evidence for retention of the ability to take up dipeptides in the presence of an amino acid transport defect. Some of the results have already been briefly reported (Tarlow et al., 1970; Matthews, 1971b).

\section{Case Report}

The patient, a boy, is the first child of Pakistani parents who are first cousins. Pregnancy and delivery were normal, and he was well until the age of 8 months, when he became constipated, apathetic, and refused to feed. During the next few weeks he developed diarrhoea and lost weight. Symptoms were not influenced by the withdrawal of various sugars or of milk protein from the diet, and because of clinical deterioration he was treated with ACTH. Improvement was prompt with return of appetite and weight gain. At the age of 1.1 years he was referred to The Hospital for Sick Children, Great Ormond Street, for further investiga- 
tion. On admission his weight was $8.0 \mathrm{~kg}$ (below 3 rd centile) and length $74 \mathrm{~cm}$ (between 10th and 25th centiles). There were no other abnormalities on physical examination and his developmental age corresponded with his chronological age. His appetite was good and he was eating a normal ward diet. ACTH was stopped as a prelude to investigation; clinical deterioration occurred within 2 weeks and he again became anorexic and lost weight.

Relevant investigations at this stage showed $\mathrm{Hb} 8 \cdot 0$ $\mathrm{g} / 100 \mathrm{ml}$, serum cholesterol $96 \mathrm{mg} / 100 \mathrm{ml}$, serum folate $10.4 \mathrm{ng} / \mathrm{ml}$, and serum iron $28 \mu \mathrm{g} / 100 \mathrm{ml}$. Faecal fat was $4.0 \mathrm{~g} /$ day (mean of 3 days) on a total fat intake of $20 \mathrm{~g} /$ day. Barium meal showed widening of the small bowel lumen, with thickened mucosal folds. Peroral biopsy of the duodenal mucosa showed subtotal villous atrophy. Examination of the urine showed constant aminoaciduria (details given in a later section) but there was no proteinuria, glycosuria, or phosphaturia, and the urinary sediment was normal. Renal acidification was also normal. There was no increase in plasma amino acids.

A provisional diagnosis of coeliac disease was made and a gluten-free, disaccharide-free diet started. Shortly afterwards (1 week after starting the diet and 7 weeks after admission) there was further marked deterioration in his condition, with complete food refusal so that gavage feeding had to be instituted. A rash resembling that of pellagra developed; this consisted of a symmetrical erythematous eruption on the face, especially on the eyelids and around the mouth, and an erythematous hyperpigmented hyperkeratotic eruption particularly marked over the napkin area and thighs. An area of punctate perifollicular haemorrhages consistent with scurvy was present on the anterior abdominal wall. A vitamin $\mathrm{C}$ saturation test showed that only $14 \%$ of the dose was excreted in 3 hours (normal $50 \%$ ). There was no suggestion of light sensitivity at this time, but the child had not in fact been outside a hospital ward, or exposed to bright sunlight, for several months. No evidence of cerebellar ataxia, or of any specific neurological deficit was detected at any time. Intravenous vitamins ('Parentrovite': $B_{1} 33 \mathrm{mg}$, nicotinamide $53 \mathrm{mg}$, riboflavine $1.3 \mathrm{mg}, B_{6} 16.5 \mathrm{mg}$, and ascorbic acid $100 \mathrm{mg}$ daily) were given and both types of skin eruption cleared within 72 hours. The gluten-free diet was continued and he subsequently made satisfactory progress with return of normal appetite and bowel habit and gain in weight to $10.8 \mathrm{~kg}$ (25th centile). He was discharged home at the age of 1.4 years clinically well on a gluten-free and disaccharide-free diet with additional oral iron and vitamin supplements ('Ketovite' tablets 9 daily, and 'Ketovite' liquid $10 \mathrm{ml}$ daily, which supplied $30 \mathrm{mg}$ nicotanamide and $150 \mathrm{mg}$ ascorbic acid).

After discharge he remained symptom free, but his growth progress was not entirely satisfactory, and it became clear that a strictly gluten-free diet was not being maintained. He was therefore readmitted for reassessment at the age of 2.4 years when his weight was $13.4 \mathrm{~kg}$ (on the 50 th centile) and height $85 \mathrm{~cm}$ (on the 10th centile). There was no neurological or intellectual deficit, and no rash. Peroral intestinal biopsy from the region of the ligament of Treitz again showed subtotal villous atrophy with considerable epithelial dysplasia. The aminoaciduria was still present (see later section). Disaccharides were introduced into his diet without any clinical reaction or the appearance of sugar in stools or urine; a strict glutenfree diet was re-established and he was discharged on this regimen together with additional vitamins as previously, and a further $50 \mathrm{mg}$ nicotinamide daily. Subsequent clinical progress was improved and by the age of 3.4 years his weight $(16.5 \mathrm{~kg})$ was on the 75 th centile and height $(98 \mathrm{~cm})$ on the 50 th centile.

\section{Special Studies of Amino Acids and of Peptide Absorption}

1st admission. Two-dimensional paper chromatography showed that the plasma amino acid pattern was normal, but revealed a constant heavy aminoaciduria, with large amounts of asparagine, glutamine, serine, threonine, alanine, phenylalanine, tyrosine, and histidine; proline was absent. No glycosuria was detected.

During this admission, but at a time when he was clinically well (i.e. after clinical response to the glutenfree diet had been established), oral loads of L-phenylalanine, L-valine, and L-histidine $(100 \mathrm{mg} / \mathrm{kg}$ body weight), and L-tyrosine $(300 \mathrm{mg} / \mathrm{kg})$ were given with a marker (Seakins and Ersser, 1967). Faecal amino acids were estimated after all four loads and serial plasma values were measured after phenylalanine and valine. No excess amino acid was found in the marked stools passed after the loads of phenylalanine, valine, and histidine, but approximately half the tyrosine given was recovered in the corresponding stool (normal values less than $10 \%$ of dose). The plasma curves for phenylalanine and valine were within the normal ranges obtained in the laboratory.

2nd admission. At this time when he was clinically well, but still had subtotal villous atrophy, urinary amino acid chromatography showed gross aminoaciduria as previously. The following loads were given on alternate days: L-tyrosine $(100 \mathrm{mg} / \mathrm{kg})$, Lhistidine $(100 \mathrm{mg} / \mathrm{kg})$, and equivalent molar quantities of glycyl-L-tyrosine and glycyl-L-histidine. Plasma samples were obtained at 30-minute intervals for 3 hours and the results are shown in Fig. 1 and 2 . Urine was collected for 6 hours after each load. Urine and plasma amino acid concentrations were assayed by ion-exchange chromatography (Thomas, 1970). The system used was designed for protein hydrolysates, and it was not possible to quantitate asparagine, glutamine, serine, and threonine because of overlapping.

The collection of timed urine and plasma samples during these loads enabled several estimations of renal clearance rates for 13 amino acids over the 6-hour period of the test to be made. In calculating mean clearance rates, values for clearance of the amino acids present in the oral load in the free form or as peptide 


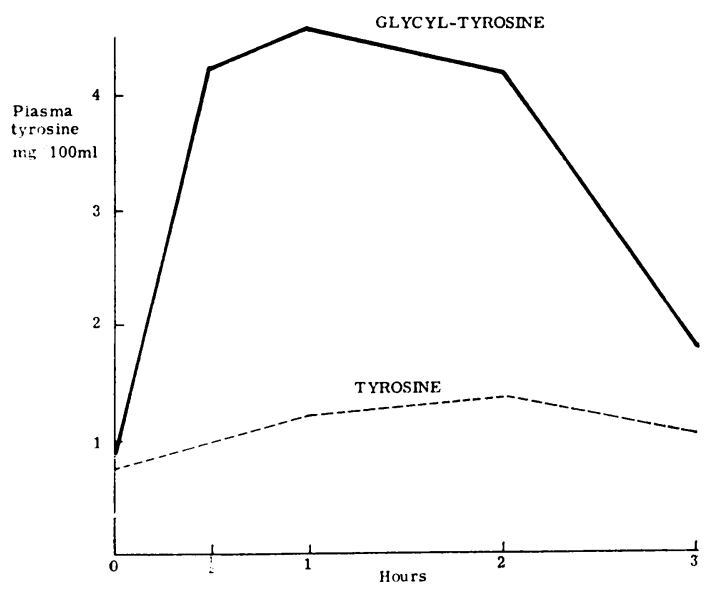

FIG. 1.-Plasma concentrations of tyrosine after oral loads of L-tyrosine (100 mg/kg body weight) and the equivalent molar quantity of glycyl-L-tyrosine. Reproduced by permission of the Editor of the British Medical Journal (1971), 3, 659.

were omitted. Clearance rates were also determined on two 24-hour urine samples. These calculated clearances are shown in Table I, where they are compared with normal values and those from one of the Hartnup family (Cusworth and Dent, 1960).

The fasting plasma values for glycine, alanine, valine, methionine, leucine, tyrosine, phenylalanine, and histidine were significantly lower than normal fasting values $(P<0.001)$ but rose to normal nonfasting values after food.

In vitro studies of jejunal mucosal uptake of amino acids from free histidine and the dipeptide glycylhistidine were carried out as follows. Part of the jejunal biopsy from the patient was divided into halves, (A)

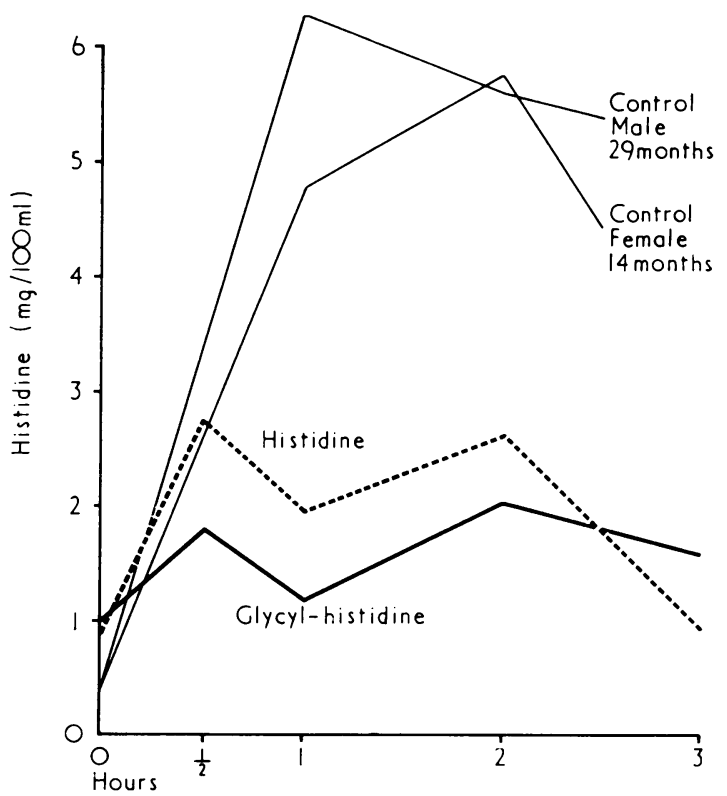

FIG. 2.-Plasma concentrations of histidine after oral loads of L-histidine (100 mg/kg body weight) and the equivalent molar quantity of glycyl-L-histidine. The plasma responses of 2 children (with normal absorption) to equivalent loads of histidine are shown for comparison (the histidine was given as part of a 'Bovril' stimulation test for the investigation of plasma growth hormone).

and (B). (A) was incubated with shaking under oxygen for 10 minutes at $37^{\circ} \mathrm{C}$ in $1 \mathrm{ml} \mathrm{Krebs-Ringer} \mathrm{phosphate}$ saline containing L-histidine $5 \mu \mathrm{mol} / \mathrm{ml}$. (B) was incubated similarly in phosphate saline containing glycyl-L-histidine $5 \mu \mathrm{mol} / \mathrm{ml}$. After blotting and

TABLE I

Renal Amino Acid Clearances (ml/min per $1.73 \mathrm{~m}^{2}$ )

\begin{tabular}{|c|c|c|c|c|c|}
\hline \multirow{2}{*}{ Amino Acid } & \multicolumn{3}{|c|}{ 6-hour Fasting } & \multicolumn{2}{|c|}{ 24-hour Fasting } \\
\hline & $\begin{array}{l}\text { Controls } \\
(n=12)\end{array}$ & $\begin{array}{l}\text { Patient } \\
(n=4)\end{array}$ & $\begin{array}{l}\text { Edward } \\
\text { Hartnup }\end{array}$ & $\begin{array}{l}\text { Normalst } \\
(n=40)\end{array}$ & $\begin{array}{c}\text { Patient (Mean } \\
\text { of } 2 \text { Values) }\end{array}$ \\
\hline $\begin{array}{l}\text { Aspartic acid } \\
\text { Glutamic acid } \\
\text { Glycine } \\
\text { Alanine } \\
\text { Valine } \\
\text { Cystine } \\
\text { Methionine } \\
\text { Isoleucine } \\
\text { Leucine } \\
\text { Tyrosine } \\
\text { Phenylalanine } \\
\text { Histidine } \\
\text { Lysine }\end{array}$ & $\begin{array}{c}3 \cdot 61 \pm 0 \cdot 88 \\
4 \cdot 24 \pm 1 \cdot 41 \\
0 \cdot 82 \pm 0 \cdot 38 \\
0 \cdot 23 \pm 0 \cdot 11 \\
0 \cdot 75 \pm 0 \cdot 20 \\
0 \cdot 81 \pm 0 \cdot 27 \\
0 \cdot 32 \pm 0 \cdot 09 \\
0 \cdot 49 \pm 0 \cdot 15 \\
2 \cdot 04 \pm 0 \cdot 80 \\
1 \cdot 50 \pm 0 \cdot 29 \\
9 \cdot 51 \pm 2 \cdot 63 \\
1 \cdot 16 \pm 0 \cdot 38\end{array}$ & $\begin{array}{c}4 \cdot 2 \pm 1 \cdot 9 \\
0 \cdot 7 \pm 0 \cdot 2 \\
3 \cdot 4 \pm 0 \cdot 7 \\
9 \cdot 2 \pm 2 \cdot 5 \ddagger \\
1 \cdot 1 \pm 0 \cdot 5 \ddagger \\
2 \cdot 6 \pm 0 \cdot 6 \ddagger \\
3 \cdot 2 \pm 1 \cdot 3 \ddagger \\
0 \cdot 9 \pm 0 \cdot 1 \ddagger \\
2 \cdot 0 \pm 0 \cdot 9 \ddagger \\
14 \cdot 6 \pm 1 \cdot 6 \ddagger \\
6 \cdot 7 \pm 0 \cdot 6 \ddagger \\
66 \cdot 5 \pm 12 \cdot 1 \ddagger \\
5 \cdot 4 \pm 2 \cdot 0 \ddagger\end{array}$ & $\begin{array}{r}17 \cdot 0 \\
5 \cdot 4 \\
16 \cdot 0 \\
23 \cdot 0 \\
16 \cdot 0 \\
3 \cdot 0 \\
22 \cdot 0 \\
26 \cdot 0 \\
15 \cdot 0 \\
49 \cdot 0 \\
21 \cdot 0 \\
66 \cdot 0 \\
6 \cdot 8\end{array}$ & $\begin{array}{l}0 \cdot 41 \pm 0 \cdot 33 \\
1 \cdot 25 \pm 1 \cdot 04 \\
4 \cdot 36 \pm 1 \cdot 79 \\
0 \cdot 93 \pm 0 \cdot 36 \\
0 \cdot 14 \pm 0 \cdot 10 \\
4 \cdot 63 \pm 1 \cdot 83 \\
0 \cdot 68 \pm 0 \cdot 44 \\
0 \cdot 40 \pm 0 \cdot 17 \\
0 \cdot 62 \pm 0 \cdot 32 \\
0 \cdot 75 \pm 0 \cdot 32 \\
0 \cdot 44 \pm 0 \cdot 32 \\
5 \cdot 38 \pm 2 \cdot 57 \\
1 \cdot 85 \pm 1 \cdot 00\end{array}$ & $\begin{array}{l}2 \cdot 7 \\
0 \cdot 3 \\
3 \cdot 6 \\
6 \cdot 8 \ddagger \\
1 \cdot 4 \ddagger \\
0 \cdot 3 \\
1 \cdot 4 \\
0 \cdot 3 \\
1 \cdot 0 \\
13 \cdot 0 \ddagger \\
4 \cdot 8 \ddagger \\
38 \cdot 7 \ddagger \\
1 \cdot 3\end{array}$ \\
\hline
\end{tabular}

$\star^{\star}$ Brodehl and Gellissen (1968). †Plum (1970). †Statistically significant $(P<0 \cdot 01)$. 
weighing, the specimens were eluted with boiling water and amino acids estimated as above. Part of a control biopsy showing subtotal villous atrophy due to coeliac disease taken for diagnostic purposes from a child aged 3 years was incubated in $L$-histidine $5 \mu \mathrm{mol} / \mathrm{ml}$ under similar conditions. Amino acid uptake and concentration in intracellular water were calculated as by Cheng et al. (1971) using figures for total water content and extracellular space given by Steiner, Farrish, and Gray (1969). Uptake of glycine from glycylhistidine by Hartnup biopsy portion (B) was calculated on the assumption that the initial glycine content of this specimen was the same as the final glycine content of portion (A). Uptakes of histidine were taken to be equal to the final content of histidine in intracellular water, since the histidine content of unincubated control biopsies was found to be negligible (c. 0.1 $\mu \mathrm{mol} / \mathrm{g}$ wet $\mathrm{wt})$. Results are given in Table II.

\section{Discussion}

The diagnosis of coeliac disease in our patient rests on the typical appearance of the small intestinal mucosa and the response to a gluten-free diet. The persistent abnormality in the intestinal mucosa at the time of the second admission is explained by the failure to adhere to a strictly gluten-free diet, and though dietary control was improved thereafter with subsequent acceleration in both height and weight gain, the religious beliefs and language problems of the family make it unlikely that a completely gluten-free diet will ever be achieved at home.

The diagnosis of Hartnup disease was suggested by the finding of a constant neutral aminoaciduria and the development of a pellagrous rash which rapidly cleared on the administration of an intravenous multivitamin preparation containing nicotinamide. There is no suggestion in the literature of any connexion between coeliac disease and Hartnup disease, and the persistence of the amino- aciduria in our patient after the initial malnutrition had been corrected virtually eliminates the possibility that the aminoaciduria was secondary to the coeliac disease. It may be, though, that the added malnutrition of coeliac disease provoked clinical manifestations of Hartnup disease in a patient who would otherwise have been asymptomatic. It has been pointed out by other workers that clinical symptoms of Hartnup disease are often preceded by a period of undernutrition (Jepson, 1966; Navab and Asatoor, 1970).

More detailed studies of the amino acid transport defect in our patient showed that it differed in certain respects from that found in classical Hartnup disease. The renal clearance of the branched chain amino acids was only slightly raised above normal. The absorption of histidine and tyrosine, two amino acids which had the highest renal clearance, was poor as judged by the plasma response after oral loads, and in the case of tyrosine by the appearance of an excess of this amino acid in the faeces. In contrast, oral loading tests failed to show impaired absorption of valine and phenylalanine, two amino acids with only slightly raised renal clearances. It is concluded therefore that our patient exhibits a variant of Hartnup disease, and if this interpretation of the experimental data is correct, the absorption of the branched chain amino acids may differ in some respects from that of the other neutral amino acids.

A reduced ability of intestinal biopsy specimens to concentrate dibasic amino acids and cystine has been shown in cystinuria (Thier et al., 1965; McCarthy et al., 1964); more recently, a reduction in biopsy uptake of tryptophan and methionine has been shown in Hartnup disease (Shih et al., 1971).

Our studies extend these observations and provide

TABLE II

Results of Incubation of Jejunal Biopsies in Free Histidine and in Equimolar Concentration of Glycylhistidine

\begin{tabular}{|c|c|c|c|c|c|c|c|}
\hline \multirow[t]{2}{*}{ Biopsy } & \multicolumn{2}{|c|}{ Incubation Medium } & \multicolumn{2}{|c|}{$\begin{array}{l}\text { Tissue Uptake } \\
(\mu \mathrm{mol} / \mathrm{g} \text { wet wt })\end{array}$} & \multicolumn{2}{|c|}{$\begin{array}{l}\text { Final Concentrations } \\
\text { in Intracellular } \\
\text { Water (ICW) } \\
(\mu \mathrm{mol} / \mathrm{ml})\end{array}$} & \multirow{2}{*}{$\begin{array}{c}\text { Distribution } \\
\text { Ratio: } \\
\text { Histidine in } \\
\text { ICW/Histidine } \\
\text { in Medium }\end{array}$} \\
\hline & $\begin{array}{l}\text { Initial Concn } \\
(\mu \mathrm{mol} / \mathrm{ml})\end{array}$ & $\begin{array}{l}\text { Final Concn } \\
(\mu \mathrm{mol} / \mathrm{ml})\end{array}$ & Histidine & Glycine & Histidine & Glycine & \\
\hline $\begin{array}{l}\text { Hartnup (A) } \\
\text { Hartnup (B) }\end{array}$ & $\begin{array}{l}\text { Histidine } 5 \cdot 0 \\
\text { Glycylhistidine } 5 \cdot 0 \\
\text { Histidine } 5 \cdot 0\end{array}$ & $\begin{array}{l}\text { Histidine } 4 \cdot 96^{\star} \\
\text { Glycylhistidine } 4 \cdot 6 \\
\text { Glycine } 0 \cdot 22 \\
\text { Histidine } 0 \cdot 27 \\
\text { Histidine } 4 \cdot 97^{\star}\end{array}$ & $\begin{array}{l}1 \cdot 0 \\
3 \cdot 7\end{array}$ & $\overline{4 \cdot 8}$ & $\begin{array}{l}1 \cdot 7 \\
6 \cdot 4\end{array}$ & $\begin{array}{l}4 \cdot 6 \\
12 \cdot 9\end{array}$ & $\begin{array}{l}0 \cdot 34 \\
23 \cdot 7\end{array}$ \\
\hline
\end{tabular}

^Calculated from tissue uptake.

Note: No intact peptide was found in the tissue incubated with glycylhistidine; total hydrolysis of peptide by this specimen was 18 $\mu \mathrm{mol} / \mathrm{g}$ wet wt. 
the first evidence that an amino acid (histidine) for which there is an intestinal transport defect is taken up by intestinal mucosa in vitro to a much greater extent when presented in the form of a dipeptide. The biopsy from our 'Hartnup' patient took up histidine very poorly from the free amino acid and failed to concentrate it under conditions in which a control biopsy (also affected by coeliac disease) took up 6 times as much histidine and concentrated it against a gradient. When incubated in glycylhistidine, however, the 'Hartnup' biopsy took up more than 3 times as much histidine as from the free amino acid. Histidine uptake from this peptide was nearly as great as that of glycine (an amino acid which is unaffected or only minimally affected by the transport defect of Hartnup disease). The possibility that the threefold difference in uptake of histidine from free amino acid and dipeptide was the result of chance variation between two halves of the same biopsy specimen is remote. Steiner et al. (1969) reported that estimates of amino acid uptake by duplicate biopsy specimens agreed within $\pm 10 \%$. An interesting feature of this case is that though the biopsy showed evidence of ability to take up histidine from glycylhistidine, the tolerance curves did not suggest that histidine absorption from this peptide was any better than from the free amino acid. Shih et al. (1971), using methionine, also found a discrepancy between the results of biopsy uptake and those of a tolerance test. The reasons for such discrepancies are unknown. It may be that the tehaviour of a biopsy from one site does not reflect the behaviour of the relatively large area of intestine involved in transport when a substance is given orally. In contrast to the glycylhistidine tolerance test, the glycyltyrosine tolerance test clearly showed superior absorption of the 'affected' amino acid when presented in peptide form.

The possibilities that the abnormalities of amino acid absorption were due to coeliac disease rather that Hartnup disease has to be considered. The fact that the tolerance curve for free tyrosine was flat whereas that following glycyltyrosine showed a great increase in this amino acid shows that nonspecific mucosal damage cannot be the explanation. This conclusion is supported by the ability of a jejunal biopsy from another patient with coeliac disease to concentrate free histidine. The results of toth in vivo and in vitro investigations support the hypothesis that intestinal transport of certain neutral amino acids is defective in Hartnup disease, but that the ability of the intestinal mucosa to take up dipeptides containing these amino acids is retained. They confirm that intestinal uptake of peptides plays a part in protein absorption in man, and that this mode of absorption is likely to be of particular nutritional importance in Hartnup disease.

We thank Professor T. Oppe, St. Mary's Hospital, London, for referring this patient, Dr. W. N. Aldridge for analysis of samples from the biopsy, Mr. R. S. Ersser and Mr. C. Dykes for technical assistance, the Joint Research Board of The Hospital for Sick Children and the Institute of Child Health, and the Variety Club of Great Britain for financial support.

\section{REFERENCES}

Adibi, S. A. (1971). Intestinal transport of dipeptides in man: relative importance of hydrolysis and intact absorption. fournal of Clinical Investigation, 50, 2266.

Asatoor, A. M., Cheng, B., Edwards, K. D. G., Lant, A. F., Matthews, D. M., Milne, M. D., Navab, F., and Richards, A. J. (1970). Intestinal absorption of two dipeptides in Hartnup disease. Gut, 11, 380.

Asatoor, A. M., Crouchman, M. R., Harrison, A. F., Light, F. W., Loughridge, L. W., Milne, M. D., and Richards, A. J. (1971). Intestinal absorption of oligopeptides in cystinuria. Clinical Science, 41, 23.

Brodehl, J., and Gellissen, K. (1968). Endogenous renal transport of free amino acids in infancy and childhood. Pediatrics, 42, 395.

Cheng, B., Navab, F., Lis, M. T., Miller, T. N., and Matthews, D. M. (1971). Mechanisms of dipeptide uptake by rat small intestine in vitro. Clinical Science, 40, 247.

Craft, I. L., Geddes, D., Hyde, C. W., Wise, I. J., and Matthews, D. M. (1968). Absorption and malabsorption of glycine and glycine peptides in man. Gut, 9, 425.

Cusworth, D. C., and Dent, C. E. (1960). Renal clearances of amino acids in normal adults and patients with aminoaciduria. Biochemical fournal, 74, 550.

Hellier, M. D., Perrett, D., and Holdsworth, C. D. (1970). Dipeptide absorption in cystinuria. British Medical fournal, 4, 782.

Jepson, J. B. (1966). Hartnup disease. In The Metabolic Basis of Inherited Disease, 2nd ed., p. 1283. Ed. by J. B. Stanbury, J. B. Wyngaarden, and D. S. Fredrickson. McGraw-Hill, New York.

McCarthy, C. F., Borland. J. L., Jr., Lynch, H. J., Jr., Owen, E. E., and Tyor, M. P. (1964). Defective uptake of basic amino acids and L-cystine by intestinal mucosa of patients with cystinuria. fournal of Clinical Investigation, 43, 1518.

Matthews, D. M. (1971a). Protein absorption. Journal of Clinical Pathology, 24, Suppl. (Roy. Coll. Path.), 5, 29.

Matthews, D. M. (1971b). Experimental approach in chemical pathology. British Medical fournal, 3, 659.

Navab, F., and Asatoor, A. M. (1970). Studies on intestinal absorption of amino acids and a dipeptide in a case of Hartnup disease. Gut, 11, 373.

Newey, H., and Smyth, D. H. (1959). The intestinal absorption of some dipeptides. Fournal of Physiology, 145, 48.

Plum, C. M. (1970). Technicon Amino Acid Symposium, London. (In press.)

Seakins, J. W. T., and Ersser, R. S. (1967). Effects of amino acid loads on a healthy infant with the biochemical features of Hartnup disease. Archives of Disease in Childhood, 42, 682.

Shih, V. E., Bixby, E. M., Alpers, D. H., Bartsocas, C. S., and Thier, S. O. (1971). Stucies of intestinal transport defect in Hartnup disease. Gastroenterology, 61, 445.

Steiner, M., Farrish, G. C. M., and Gray, S. J. (1969). Intestinal uptake of valine in calorie and protein deprivation. American fournal of Clinical Nutrition, 22, 871.

Tarlow, M. J., Seakins, J. W. T., Lloyd, J. K., Matthews, D. M., Cheng, B., and Thomas, A. J. (1970). Intestinal absorption and biopsy transport of peptides and amino acids in Hartnup disease. Clinical Science, 39, $18 \mathrm{P}$. 
Thier, S. O., Segal, S., Fox, M., Blair, A., and Rosenberg, L. E. (1965). Cystinuria: defective intestinal transport of dibasic amino acids and cystine. Fournal of Clinical Investigation, 44, 442.

Thomas, A. J. (1970). Automation, Mechanization and Data Handling in Microbiology, p. 107. Ed. by A. Baillie and R. J. Gilbert. Academic Press, New York and London.

Correspondence to Dr. J. K. Lloyd, Institute of Child Health, Guilford Street, London WC1 $1 \mathrm{EH}$.

\section{Addendum}

Since this paper was submitted, a further child (boy) has been born into the family. Investigation of his urinary amino acids and clearances at the age of 3 weeks showed a pattern similar to that present in our patient. We are grateful to Dr. P. J. N. Cox for permission to report this fact. 